\title{
Physiological and anatomical characteristics of leaves of two clones of guarana
}

\author{
José Francisco de Carvalho Gonçalves ${ }^{(1)}$, Ulysses Moreira dos Santos Júnior(1), José Ferreira da Silva(2), \\ Murilo Rodrigues de Arruda $^{(3)}$, Luiz Carlos de Matos Bonates ${ }^{(1)}$ and Andreia Varmes Fernandes ${ }^{(1)}$
}

\begin{abstract}
(1)Instituto Nacional de Pesquisas da Amazônia, Laboratório de Fisiologia e Bioquímica Vegetal, Caixa Postal 478, CEP $69011-970$ Manaus, AM, Brazil. E-mail: jfc@inpa.gov.br (2)Universidade Federal do Amazonas, Fac. de Ciências Agrárias, Campus Universitário, CEP 69077-000 Manaus, AM, Brazil. E-mail: jfsilva@ufam.edu.br ${ }^{(3)}$ Embrapa Amazônia Ocidental, Caixa Postal 319, CEP 69011-970 Manaus, AM, Brazil. E-mail: murilo@cpaa.embrapa.br
\end{abstract}

\begin{abstract}
The objective of this work was to analyze gas exchange, photosynthetic characteristics, photochemical efficiency of photosystem II and anatomical characteristics of young plant leaves of two guarana (Paullinia cupana) clones (BRS-CG372RC and BRS-CG611RL) growing under open field. The variables of gas exchange and fluorescence of chlorophyll a were evaluated in mature leaves. The values of photosynthesis and transpiration found for BRS-CG372RC were 27\% greater and 80\% lesser than values found for BRS-CG611RL, respectively. The values of stomatal conductance found for the clones BRS-CG372RC and BRS-CG611RL were in the order of 224 and $614 \mathrm{mmol} \mathrm{mm}^{-2} \mathrm{~s}^{-1}$, respectively. The values of photorespiration, rate of carboxylation and rate electron transport were greater in BRS-CG372RC. The clone BRS-CG372RC exhibited stomatal density $26 \%$ greater than BRS-CG611RL. However, the area of ostiolar opening was 42\% greater in BRS-CG611RL. The values of the water use efficiency in BRS-CG372RC were 134\% greater than in BRS-CG611RL. High stomatal density and low stomatal conductance can be important characteristics in the selection of the clones with a good ability to assimilate carbon and optimize the use of water.
\end{abstract}

Index terms: Paullinia cupana, photosynthesis, photochemical efficiency of photosystem II, electron transport rate, water use efficiency, stomatal anatomy.

\section{Características fisiológicas e anatômicas de folhas de dois clones de guaraná}

Resumo - O objetivo deste trabalho foi analisar as trocas gasosas, as características fotossintéticas, a eficiência fotoquímica do fotossistema II e as características anatômicas foliares de plantas jovens de dois clones de guaraná desenvolvidas a pleno sol. As variáveis de trocas gasosas e fluorescência da clorofila a foram determinadas em folhas maduras. Os valores de fotossíntese e transpiração encontrados para BRS-CG372RC foram 27\% maiores e 80\% menores que os valores encontrados para BRS-CG611RL, respectivamente. Os valores de condutância estomática dos clones BRS-CG372RC e BRS-CG611RL foram de aproximadamente 224 e $614 \mathrm{mmol} \mathrm{m}^{-2} \mathrm{~s}^{-1}$, respectivamente. Os valores de fotorrespiração, taxa de carboxilação e taxa de transporte de elétrons foram maiores em BRS-CG372RC. O clone BRS-CG372RC apresentou densidade estomática 26\% maior que BRS-CG611RL. A área de abertura do ostíolo foi 42\% maior em BRS-CG611RL. O valor da eficiência no uso da água em BRS-CG372RC foi 134\% maior que em BRS-CG611RL. Alta densidade estomática e baixa condutância estomática são características importantes para a seleção de clones com boa capacidade para assimilar carbono e que sejam eficientes no uso da água.

Termos para indexação: Paullinia cupana, fotossíntese, eficiência fotoquímica do fotossistema II, taxa de transporte de elétrons, eficiência no uso da água, anatomia de estômatos.

\section{Introduction}

Among the many Amazonian species that are recognized for their economic potential, guarana (Paullinia cupana var. sorbilis (Mart.) Ducke), a member of the Sapindaceae family (Nascimento Filho et al., 2001), is one that particularly stands out. The commercial products of this species are taken from its seeds, which have medicinal and stimulant properties (Henman, 1986) as well as high concentrations of caffeine. The levels of caffeine in Paullinia cupana seeds can vary between 2.7 and 5.8\% (Henman, 1982), up to three times greater than the levels found in Coffea sp. Apart from caffeine, Paullinia cupana 
seeds are also an important source of theobromine (a substance which dilates blood vessels) and theophylline (a substance which dilates the bronchials) (Henman, 1986).

Due to the large demand in the soft drink and health food industries, it is necessary to increase the production and productivity of $P$. cupana seeds. For this reason, investment in the study of clones with a potential to increase productivity has been the focus of programs designed to produce more productive varieties.

Even when considering that productivity is a genetically-determined characteristic that is controlled by abiotic factors (water, $\mathrm{CO}_{2}$, irradiance, temperature, nutrients), it is understood that the structure and functionality of certain tissues may have an important influence on factors that affect primary productivity. In this manner, structural aspects, like the number and size of the stomata, can be determinant to the development of the plant. By controlling the stomatal opening, plants are able to adjust the diffusive resistance of $\mathrm{CO}_{2}$ and water under conditions of continual environmental change. As a result of the specific functions that they execute, the stomata suffer direct influence of factors that are both endogenic (nutrients, genetic influences and phytohormones) and exogenic (irradiance, humidity, wind and temperature) (Kramer \& Boyer, 1995; Eckstein et al., 1996). In the face of these factors, plants regulate transpiration and $\mathrm{CO}_{2}$ assimilation, determinants of its survival, as well as the accumulation of biomass and adaptation to different environments.

The objective of this work was to analyze gas exchange, photosynthetic characteristics, photochemical efficiency of photosystem II and anatomical characteristics of the young plants of two Paullinia cupana clones (BRS-CG611RL and BRS-CG372RC).

\section{Material and Methods}

The experiment was conducted under semi-controlled conditions in a greenhouse at the Instituto Nacional de Pesquisas da Amazônia, Manaus, AM, Brazil (3º's, $\left.59^{\circ} 52^{\prime} \mathrm{W}\right)$. According to Köppen's climatic classification, the climate of the region is an Afi type, with average annual precipitation of 2,200 $\mathrm{mm}$ and average annual temperature of $26.7^{\circ} \mathrm{C}$.

The experiment was conducted using young plants of two guarana clones of Paullina cupana (Mart.) Ducke, six to seven months old, grown in natural sunlight. The clones used were BRS-CG611RL (long branch) and
BRS-CG372RC (short branch) grown under nursery conditions at Embrapa Amazônia Ocidental, Manaus, AM. Ten plants per clone were utilized. The young plants were selected following a standard model of uniformity, size and appropriate phytosanitary state. After asepsis, the cuttings from those plants were rooted with AIB ( $5 \mathrm{~g} \mathrm{~L}^{-1}$ powder) and placed in $5 \mathrm{~kg}$ plastic bags with sand used as substrate. Afterwards, plants were submmited to intermittent nebulization. Following the period of rooting (four months), the plants were selected and submmited to a period of acclimation (two months) to conditions of direct sunlight (until 2,300 $\mu \mathrm{mol} \mathrm{m}^{-2} \mathrm{~s}^{-1}$ in the hours of higher irradiance). During the experimental period (two months), plants were irrigated when necessary in order to maintain field capacity. After one month of acclimation during the experimental period, physiological and anatomical analyses of $P$. cupana clones were carried out.

Photosynthesis $\left(A_{\max }\right)$, dark respiration $\left(\mathrm{R}_{\mathrm{d}}\right)$, stomatal conductance $\left(\mathrm{g}_{\mathrm{s}}\right)$ and transpiration (E) were measured with the use of an infrared gas analyser (IRGA), a Portable Photosynthesis System, model LI-6400 (Li-Cor, Lincoln, NE, USA), following the methodology described by Marenco et al. (2001). The measurements were made between $9 \mathrm{~h}$ and $13 \mathrm{~h}$ in completely expanded leaves of appropriate phytosanitary states, situated in the middle third of the plant. There were ten repetitions for each clone. Gas exchange data obtained in the leaf chambers was adjusted to conduct analyses with $\mathrm{CO}_{2}$ concentrations and water vapor of $385 \pm 10 \mu \mathrm{mol} \mathrm{mol}^{-1}$ and $21 \pm 1 \mathrm{mmol} \mathrm{mol}^{-1}$, respectively. The temperature was controlled at $31 \pm 1^{\circ} \mathrm{C}$.

The photosynthetic response to light intensity curve was adjusted for each plant with the model of the nonrectangular hyperbole according to Lieth \& Reynolds (1987):

$\mathrm{A}=\left\{\left[\left(\phi_{\mathrm{a}} \mathrm{I}+\mathrm{A}_{\text {max }}^{\prime}+\mathrm{R}_{\mathrm{d}}\right)-\left(\left(\phi_{\mathrm{a}} \mathrm{I}+\mathrm{A}_{\text {max }}+\mathrm{R}_{\mathrm{d}}\right)^{2}-\right.\right.\right.$ $\left.\left.\left.4 \phi_{\mathrm{a}} \mathrm{I} \theta\left(\mathrm{A}^{\prime}{ }_{\text {max }}+\mathrm{R}_{\mathrm{d}}\right)\right)^{0,5}\right] / 2 \theta\right\}-\mathrm{R}_{\mathrm{d}}$

in which A represents the net photosynthetic rate $[\mu \mathrm{mol}$ $\left(\mathrm{CO}_{2}\right) \mathrm{m}^{-2} \mathrm{~s}^{-1}$, $\mathrm{A}_{\text {max }}^{\prime}$ represents the photosynthetic rate under conditions of saturated light, $\mathrm{R}_{\mathrm{d}}$ represents the dark respiration, $\phi_{\mathrm{a}}$ represents the apparent quantum yield [mol $\left(\mathrm{CO}_{2}\right) \mathrm{mol}^{-1}$ (quanta)], I represents the light intensity and $\theta$ represents the regression curve factor (curve inclination). Dark respiration was determined after an adaptive period of 15 minutes. The variable $\phi_{a}$ was estimated with the help of a linear regression from the initial portion of the curve, situated between 0 and $100 \mu \mathrm{mol} \mathrm{m}{ }^{-2} \mathrm{~s}^{-1}$. The values $\mathrm{A}_{\text {max }}$ and $\theta$ were estimated 
using the non-rectangular hyperbole regression from the program Statistics 6.0. The value of $A_{\max }$ was estimated after the curve adjustment, corresponding to the value of A at the point where PPFD was equal to 2,000 $\mu \mathrm{mol} \mathrm{m}^{-2} \mathrm{~s}^{-1}$. Light compensation irradiance was calculated with the formula $\mathrm{I}_{\mathrm{c}}=\mathrm{R}_{\mathrm{d}} / \phi_{\mathrm{a}}$. Photorespiration $\left(\mathrm{P}_{\mathrm{r}}\right)$ was calculated as half of the rate of oxygenation $\left(\mathrm{V}_{\mathrm{o}}\right)$, according to the method described by Sharkey (1988):

$\mathrm{V}_{\mathrm{o}}=\left(\mathrm{A}+\mathrm{R}_{\mathrm{d}}\right) /[(1 / \Phi)-0.5]$,

in which $\Phi$ is a combination of the parameters found in the equation (Sharkey, 1988):

$\Phi=2 \mathrm{P}\left[42.7+1.68(\mathrm{t}-25)+0.0012(\mathrm{t}-25)^{2}\right] / \mathrm{C}_{\mathrm{i}}$,

in which $\mathrm{t}$ is the temperature $\left({ }^{\circ} \mathrm{C}\right), \mathrm{P}$ is atmospheric pressure (bar) and $\mathrm{C}_{\mathrm{i}}$ is substomatal $\mathrm{CO}_{2}$ concentrations.

The rate of carboxylation $\left(\mathrm{V}_{\mathrm{c}}\right)$ was calculated by the equation:

$\mathrm{V}_{\mathrm{C}}=\mathrm{A}+0.5 \mathrm{~V}_{\mathrm{o}}+\mathrm{R}_{\mathrm{d}}$

The electron transport rate $(\mathrm{J})$ was calculated according to Farquhar \& Caemmerer (1982):

$\mathrm{J}=4\left(\mathrm{~V}_{\mathrm{C}}+\mathrm{V}_{\mathrm{o}}\right)$.

The water use efficiency (WUE) was calculated by the equations: WUE $\left(\mathrm{mmol} \mathrm{CO} \mathrm{Col}^{-1} \mathrm{H}_{2} \mathrm{O}\right)=$ photosyntheis/transpiration. For the analysis of anatomical characteristics, $1 \mathrm{~cm}^{2}$ sections removed from the edge of the leaf were taken from three completely expanded leaves in ten individual plants for each clone studied. The disassociation of the epidermis was done in sodium hypochlorite $80 \%$ (v/v) solution. Afterwards, the epidermis was cleaned in running water, colored in Fucsin - Astrablue solution in alcoholic series mounted in 50\% glycerin and analyzed with an optic microscope using a dark camera (Leitz) connected to a microscope (Zeiss) with several magnifications. When counting the stomata, the $40 \times 10$ magnification was used with a correction factor equal to 4.21 per field. After capturing images of the leaf tissue, the stomatal length (SL), ostiolar length (OL), area of ostiolar opening (AOO), stomatal density (SD), total stomatal length (TSL = SL x SD), total ostiolar length (TOL $=$ OL $x \mathrm{SD}$ ) and porous area $(\mathrm{PA}=\mathrm{AOO} \times \mathrm{SD} \times 100)$ were measured.

The fluorescence of chlorophyll a was measured with a portable fluorometer (Plant Efficiency Analyzer-PEA, MK2-9600-Hanstech, Norfolk,UK) between 9 and 11h in leaves situated in the middle third of the plant. The repetitions were comprised of two leaves (subsamples) chosen from each treatment. The leaves of the $P$. cupana clones were subjected to a 30 minute period of adaptation to the dark and then were exposed to a pulse of 2,250 $\mu \mathrm{mol} \mathrm{m}{ }^{-2} \mathrm{~s}^{-1}$ of saturated light, measuring the fluorescence of chlorophyll a according to Gonçalves et al. (2001). After the induction of fluorescence in fast kinetic periods, initial fluorescence $\left(\mathrm{F}_{0}\right)$, maximum fluorescence $\left(F_{m}\right)$, variable fluorescence $\left(F_{v}=F_{m}-F_{0}\right)$ and photochemical efficiency of photosystem II $\left(\mathrm{F}_{\mathrm{v}} / \mathrm{F}_{\mathrm{m}}\right)$ were determined.

The experimental design was completely randomized with two treatments and ten repetitions (plants). The data were submmited to an analysis of variance and the means were compared by the Tukey test $(\mathrm{p} \leq 0.05)$. In addition, regression analyses were applied to the light curve adjustments. For the statistical analyses, the program Statistics (version 6.0) was used.

\section{Results and Discussion}

Photosynthetic rate found in the clone BRS-CG372RC was $27 \%$ greater compared with the value exhibited by the clone BRS-CG611RL (Table 1). This response of the photosynthetic rate to light intensity can be observed in Figure 1. For dark respiration, there was no difference between the two clones, however, when compared with other tropical species, it can be observed that the clones exhibited higher values (Baker et al., 1997; Reich et al., 1998), possibly as a result of the association of high irradiance with high temperatures found in tropical regions (Marenco et al., 2001). The values of $R_{d} / A_{\max }$ were 0.34 and 0.41 for BRS-CG372RC and BRS-

Table 1. Gas exchange and photosynthetic characteristics in young plants of two clones of Paullinia cupana(1). Photosynthesis $\left(\mathrm{A}_{\max } ; \mu \mathrm{mol}\left(\mathrm{CO}_{2}\right) \mathrm{m}^{-2} \mathrm{~s}^{-1}\right)$, dark respiration $\left(\mathrm{R}_{\mathrm{d}} ; \mu \mathrm{mol}\left(\mathrm{CO}_{2}\right) \mathrm{m}^{-2} \mathrm{~s}^{-1}\right)$, photorespiration $\left(\mathrm{P}_{\mathrm{r}} ; \mu \mathrm{mol}\left(\mathrm{CO}_{2}\right) \mathrm{m}^{-2} \mathrm{~s}^{-1}\right)$, rate of carboxylation $\left(\mathrm{V}_{\mathrm{c}} ; \mu \mathrm{mol}\left(\mathrm{CO}_{2}\right) \mathrm{m}^{-2} \mathrm{~s}^{-1}\right)$, electron transport rate $\left(\mathrm{J} ; \mu \mathrm{mol}\left(\mathrm{e}^{-}\right) \mathrm{m}^{-2} \mathrm{~s}^{-1}\right)$, stomatic conductance $\left(\mathrm{g}_{\mathrm{s}} ; \mathrm{mmol}\right.$ $\left.\left(\mathrm{H}_{2} \mathrm{O}\right) \mathrm{m}^{-2} \mathrm{~s}^{-1}\right)$, stomatic resistance $\left(\mathrm{R}_{\mathrm{s}} ; \mathrm{m}^{2} \mathrm{~s}^{-1} \mu \mathrm{mol}^{-1}\left(\mathrm{H}_{2} \mathrm{O}\right)\right.$ ), transpiration ( $\mathrm{E}$; mmol $\left.\left(\mathrm{H}_{2} \mathrm{O}\right) \mathrm{m}^{-2} \mathrm{~s}^{-1}\right)$, and water use efficiency (WUE; mmol $\left(\mathrm{CO}_{2}\right) \mathrm{mol}^{-1}\left(\mathrm{H}_{2} \mathrm{O}\right)$ ).

\begin{tabular}{lcc}
\hline Parameters & BRS-CG611RL & BRS-CG372RC \\
\hline Photosynthesis & $4.32 \pm 0.69 \mathrm{~B}$ & $5.49 \pm 0.69 \mathrm{~A}$ \\
Dark respiration & $1.78 \pm 0.15 \mathrm{~A}$ & $1.84 \pm 0.19 \mathrm{~A}$ \\
Photorespiration & $1.06 \pm 0.15 \mathrm{~B}$ & $1.37 \pm 0.04 \mathrm{~A}$ \\
Rate of carboxylation & $7.16 \pm 0.99 \mathrm{~B}$ & $8.70 \pm 0.91 \mathrm{~A}$ \\
Electron transport rate & $37.14 \pm 5.13 \mathrm{~B}$ & $45.74 \pm 3.83 \mathrm{~A}$ \\
Stomatic conductance & $614 \pm 71 \mathrm{~A}$ & $224 \pm 111 \mathrm{~B}$ \\
Stomatic resistance & $1.61 \pm 0.14 \mathrm{~B}$ & $5.81 \pm 2.88 \mathrm{~A}$ \\
Transpiration & $4.20 \pm 0.36 \mathrm{~A}$ & $1.38 \pm 0.33 \mathrm{~B}$ \\
Water use efficiency & $1.05 \pm 0.25 \mathrm{~B}$ & $4.31 \pm 1.53 \mathrm{~A}$ \\
\hline
\end{tabular}

(1) Mean values \pm standard deviations; each value is composed of ten repetitions; mean values followed by same letters for clones are not different at $\mathrm{p} \leq 0.05$ by the Tukey test. 
CG611RL, respectively, which were lower than expected for conditions of ambient $\mathrm{CO}_{2}$ (Amthor, 1994). In regard to photosynthetic characteristics, the value of $\phi_{a}$ for BRS-CG372RC was $24 \%$ greater than that of BRS-CG611RL (Table 2), indicating better use of incidental irradiance for the reduction of $\mathrm{CO}_{2}$.

In relation to compensation irradiance, results showed that the difference of $18 \%$ between the mean values of $\mathrm{I}_{\mathrm{C}}$ found for BRS-CG611RL and BRS-CG372RC (Table 2) were more influenced by $\phi_{a}$ than by $R_{d}$. The values for $P_{r}$ and $V_{c}$ exhibited by BRS-CG372RC were 21 to $29 \%$ greater than those for BRS-CG611RL (Table 1).

The photorespiratory process, despite restraining the accumulation of biomass, may be used to dissipate excess energy, thus avoiding photo inhibition. As a result of its higher values for $\mathrm{P}_{\mathrm{r}}$ and $\mathrm{V}_{\mathrm{c}}$, BRS-CG372RC had values of J 23\% greater than BRS-CG611RL (Table 1). From this, plants with high rates of carboxylation associated with high photorespiratory rates may exhibit better performance with respect to the accumulation of carbon under high irradiance. In addition, BRS-CG611RL showed values for transpiration and stomatal conductance approximately 80 and $174 \%$ greater than those for BRS-CG372RC, respectively. The values for

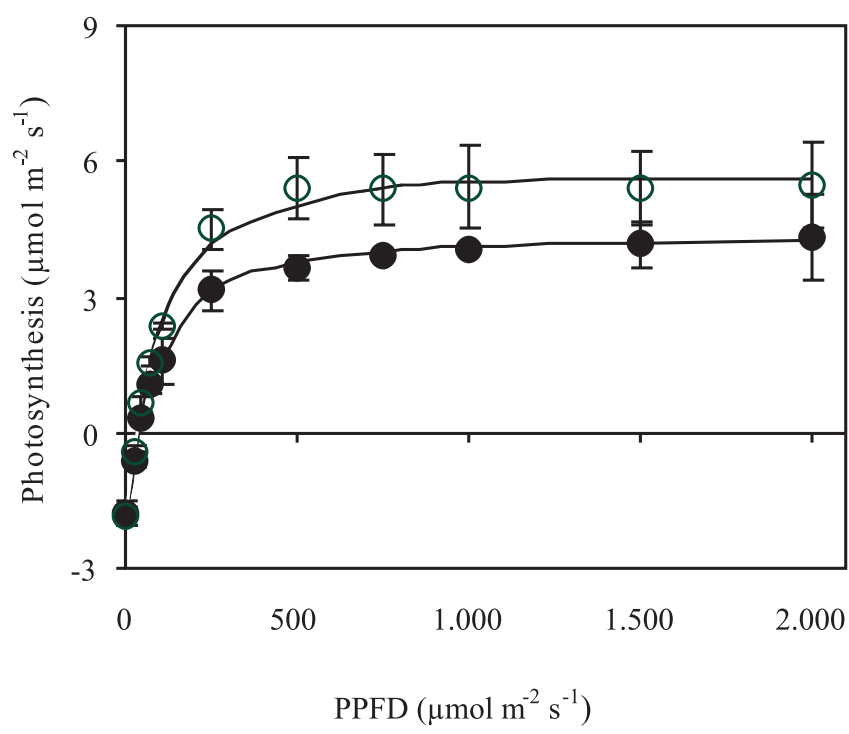

Figure 1. Effect of the photosynthetic photon flux density (PPFD) on the rate of net photosynthesis in the leaves of two clones (O) BRS-CG372RC and (•) BRS-CG611RL of Paullinia cupana. Each line represents a non-rectangular hyperbole obtained for each clone. Each value is composed of ten repetitions. For both curves, $\mathrm{R}^{2}>0.98$.
WUE in BRS-CG372RC were 134\% greater than in BRS-CG611RL. For the internal concentrations of $\mathrm{CO}_{2}$ and the relationship $\mathrm{C}_{\mathrm{i}} / \mathrm{C}_{\mathrm{a}}$, there was no difference between the two clones studied (Table 2).

With regard to the anatomical characteristics of leaf epidermis of the two P. cupana clones, the value of stomatal density in BRS-CG611RL was 26\% greater than the value in BRS-CG372RC (Table 3). However, the values for the stomatal and ostiolar length in BRS-CG611RL were 13 to $19 \%$ greater than those for BRS-CG372RC, respectively (Table 3). In addition, the average area of the ostiolar opening found for BRS-CG611RL was $41 \%$ greater than that for BRS-CG372RC. Nevertheless, there was no significant difference between the clones for the stomatal index, total ostiolar length and porous area (Table 3).

With respect to $R_{S}$, there was a difference of $252 \%$ between BRS-CG372RC and BRS-CG611RL. The greater transfer resistance of leaf water vapor to the

Table 2. Apparent quantum yield ( $\phi_{\mathrm{a}} ; \mathrm{mol}\left(\mathrm{CO}_{2}\right) \mathrm{mol}^{-1}$ (quanta)), convexity factor $(\theta$, dimensionless), compensation irradiance $\left(\mathrm{I}_{\mathrm{c}}, \mu \mathrm{mol}\right.$ (photons) $\left.\mathrm{m}^{-2} \mathrm{~s}^{-1}\right), \mathrm{CO}_{2}$ internal concentration $\left(\mathrm{C}_{\mathrm{i}}\right.$, $\mu \mathrm{mol} \mathrm{mol}{ }^{-1}$ ) and the relationship $\mathrm{C}_{\mathrm{i}} / \mathrm{C}_{\mathrm{a}}$ in young plants of two Paullinia cupana clones $^{(1)}$.

\begin{tabular}{lcc}
\hline Parameters & BRS-CG611RL & BRS-CG372RC \\
\hline Apparent quantum yield & $0.034 \pm 0.001 \mathrm{~B}$ & $0.042 \pm 0.005 \mathrm{~A}$ \\
Convexity factor & $0.95 \pm 0.01 \mathrm{~A}$ & $0.91 \pm 0.01 \mathrm{~B}$ \\
Compensation irradiance & $53 \pm 3 \mathrm{~A}$ & $45 \pm 10 \mathrm{~B}$ \\
$\mathrm{CO}_{2}$ internal concentration & $359 \pm 1 \mathrm{~A}$ & $338 \pm 30 \mathrm{~A}$ \\
$\mathrm{C}_{\mathrm{i}} / \mathrm{C}_{\mathrm{a}}$ ratio & $0.90 \pm 0.00 \mathrm{~A}$ & $0.84 \pm 0.07 \mathrm{~A}$ \\
\hline
\end{tabular}

${ }^{(1)}$ Mean values \pm standard deviations; each value is composed of ten repetitions; mean values followed by same letters for clones are not different at $\mathrm{p} \leq 0.05$ by the Tukey test.

Table 3. Anatomic characteristics of leaves from young plants of two Paullinia cupana clones $^{(1)}$.

\begin{tabular}{lcc}
\hline Parameters & BRS-CG611RL & BRS-CG372RC \\
\hline Stomatic density & $99 \pm 6 \mathrm{~B}$ & $125 \pm 5 \mathrm{~A}$ \\
Stomatic index & $0.274 \pm 0.014 \mathrm{~A}$ & $0.263 \pm 0.011 \mathrm{~A}$ \\
Stomatic length $(\mu \mathrm{m})$ & $41 \pm 3 \mathrm{~A}$ & $36 \pm 2 \mathrm{~B}$ \\
Ostiolar length $(\mu \mathrm{m})$ & $26 \pm 3 \mathrm{~A}$ & $22 \pm 1 \mathrm{~B}$ \\
Total stomatic length $(\mu \mathrm{m})$ & $4059 \pm 18 \mathrm{~B}$ & $4500 \pm 10 \mathrm{~A}$ \\
Total ostiolar length $(\mu \mathrm{m})$ & $2574 \pm 18 \mathrm{~A}$ & $2750 \pm 5 \mathrm{~A}$ \\
Area of ostiolar opening $\left(\mu \mathrm{m}^{2}\right)$ & $253 \pm 61 \mathrm{~A}$ & $179 \pm 29 \mathrm{~B}$ \\
Porous area $(\%)$ & $2.52 \pm 0.64 \mathrm{~A}$ & $2.25 \pm 0.40 \mathrm{~A}$ \\
\hline
\end{tabular}

(1)Mean values \pm standard deviations; each value is composed of ten repetitions; mean values followed by same letters for clones are not different at $\mathrm{p} \leq 0.05$ by the Tukey test. 
atmosphere in the clone BRS-CG372RC could be a result of a better adjustment of the stomata unit proportioned by a decrease in the stomatal length, ostiolar length and area of ostiolar opening when compared with BRS-CG611RL.

For the WUE, there was a negative correlation of 0.99 observed in transpiration. Additionally, the variables WUE and SD showed positive correlations of 0.55 and 0.62 in relation to photosynthesis, respectively. Conductance exhibited a positive correlation of 0.90 to transpiration. The low value of transpiration found for BRS-CG372RC could have been a result of a better regulation of the stomatal opening, indicated by the low value of the stomatal length when compared with BRS-CG611RL. The stomatal length is probably of greater significance than the stomatal density, since photosynthesis are more sensitive to stomatal density. Thus, results showed that anatomical differences between the clones could have been determinant in the different strategies used in the regulation of gas exchange. This may occur because of differences in diffusion in the processes that enable water to leave and enter the leaf. The $\mathrm{CO}_{2}$ concentration gradient between the air and chloroplast is much smaller when compared to the water vapor concentration gradient inside and outside the leaf, which explains why the loss of water occurs quicker than the absorption of $\mathrm{CO}_{2}$. Moreover, $\mathrm{H}_{2} \mathrm{O}$ molecules are smaller and they disperse 1.6 times quicker than $\mathrm{CO}_{2}$ molecules, not to mention the fact that the path of water diffusion is smaller than the path that $\mathrm{CO}_{2}$ must follow (Nobel, 1991).

In regard to the variables of the fluorescence of chlorophyll a, higher values for $\mathrm{F}_{0}, \mathrm{~F}_{\mathrm{v}}, \mathrm{F}_{\mathrm{m}}$ and $\mathrm{F}_{\mathrm{v}} / \mathrm{F}_{\mathrm{m}}$ were found in BRS-CG372RC (Table 4). In addition, the values of $F_{0}, F_{v}$ and $F_{m}$ exhibited by BRS-CG372RC were approximately 18, 85 and $60 \%$ greater than those found for BRS-CG611RL.

Table 4. Fluorescence of chlorophyll a in young plants of two Paullinia cupana clones $^{(1)}$.

\begin{tabular}{lcc}
\hline Parameters & BRS-CG611RL & BRS-CG372RC \\
\hline Initial fluorescence $\left(\mathrm{F}_{0}\right)$ & $520 \pm 58 \mathrm{~B}$ & $615 \pm 21 \mathrm{~A}$ \\
Maximum fluorescence $\left(\mathrm{F}_{\mathrm{m}}\right)$ & $1,380 \pm 270 \mathrm{~B}$ & $2,203 \pm 384 \mathrm{~A}$ \\
Variable fluorescence $\left(\mathrm{F}_{\mathrm{v}}\right)$ & $860 \pm 264 \mathrm{~B}$ & $1,588 \pm 377 \mathrm{~A}$ \\
$\mathrm{~F}_{\mathrm{v}} / \mathrm{F}_{\mathrm{m}}$ & $0.61 \pm 0.07 \mathrm{~B}$ & $0.71 \pm 0.05 \mathrm{~A}$ \\
\hline
\end{tabular}

(1) Mean values \pm standard deviations; each value is composed of ten repetitions; mean values followed by the same letters for species are not different at $\mathrm{p} \leq 0.05$ by the Tukey test.
In relation to the photochemical efficiency of PS II, the two clones had indicators for photoinhibition caused by excess irradiance. When comparing the values of $\mathrm{F}_{\mathrm{v}} / \mathrm{F}_{\mathrm{m}}$ exhibited by the two clones with the values from Björkman \& Demmig-Adams (1987) of plants without conditions of stress $\left(\mathrm{F}_{\mathrm{v}} / \mathrm{F}_{\mathrm{m}}=0.83\right)$, the clones BRS-CG372RC and BRS-CG611RL suffered photoinhibition of PS II. Photoinhibition is defined as the inhibition of photosynthesis due to excess light. When leaves are exposed to more light than they are able to use, the excess light energy absorbed can direct produce species reactive to oxygen and provoke damage in the photosynthetic mechanism (Quiles \& López, 2004). A plant's PS II quantum efficiency can also be reduced by photoinhibition when exposed to excess light energy (Krause \& Weis, 1991) - the net result of the whole complex of cellular interactions and leaf level processes (Demmig-Adams \& Adams, 1992; Björkman \& Demmig-Adams, 1994). Photoinhibition is known to occur at the level of thylacoids, particularly in PS II (Cleland et al., 1986), as a result of the degradation of protein D1 (Rintamäki et al., 1995) or photochemical inactivity at the reaction center of PS II (Aro et al., 1993), where excited energy is converted into heat.

For these reasons, the results for the fluorescence of chlorophyll a demonstrate that the two clones experienced photoinhibition when submmited to direct sunlight, in which the clone BRS-CG372RC showed greater photochemical efficiency in PS II, compared with BRS-CG611RL, probably a result of better use of excess energy in photochemical processes (photosynthesis).

\section{Conclusions}

1. Low stomatal conductance represents important characteristics for selection of Paullinia cupana clones with a strong capacity for carbon assimilation and efficient water use.

2. The anatomical characteristics related to the size of the stomata can be used in the selection of P. cupana clones better adapted to conditions of little water availability.

3. The greater activity involving photochemical processes (high electron transport rate) in the clone BRS-CG372RC contribute to a more significant decrease in the degree of photoinhibition, when compared with BRS-CG611RL. 


\section{Acknowledgements}

To Embrapa Amazônia Ocidental, for the donation of young plants of P. cupana; to Nicholas C. Kawa, for reviewing the manuscript.

\section{References}

AMTHOR, J.S. Higher plant respiration and its relationships to photosynthesis. In: SCHULZE, E.-D.; CALDWELL, M.M. (Ed.). Ecophysiology of photosynthesis. Berlin: Springer-Verlag, 1994. p.71-101.

ARO, E.M.; VIRGIN, I.; ANDERSSON, B. Photoinhibition of photosystem II. Inactivation, protein damage and turnover. Biochimica et Biophysica Acta, v.1143, p.113-134, 1993.

BAKER, M.G.; PRESS, M.C.; BROWN, N.D. Photosynthetic characteristics of dipterocarp seedlings in three tropical rain forest light environments: a basis for niche partitioning? Oecologia, v.112, p.453-463, 1997.

BJÖRKMAN, O.; DEMMIG-ADAMS, B. Photon yield of $\mathrm{O}_{2}$ evolution and chlorophyll fluorescence characteristics at $77 \mathrm{~K}$ among vascular plants of diverse origins. Planta, v.170, p.489-504, 1987.

BJÖRKMAN, O.; DEMMIG-ADAMS, B. Regulation of photosynthetic light energy capture, conversion, and dissipation in leaves of higher plants. In: SCHULZE, E.-D.; CALDWELL, M.M. (Ed.). Ecophysiology of photosynthesis. Berlin: Springer-Verlag, 1994. p.17-47. (Ecological studies, 100).

CLELAND, R.E.; MELIS, A.; NEALE, P.J. Mechanism of photoinhibition: photochemical reaction center inactivation in system II chloroplasts. Photosynthesis Research, v.9, p.79-88, 1986.

DEMMIG-ADAMS, B.; ADAMS III, W.W. Photoprotection and other responses of plants to high light stress. Annual Review of Plant Physiology and Plant Molecular Biology, v.43, p.599-626, 1992.

ECKSTEIN, J.; BEYSCHLAG, W.; MOTT, K.A.; RYEL, R.J. Changes in photon flux can induce stomatal patchiness. Plant, Cell and Environment, v.19, p.1066-1074, 1996.

FARQUHAR, G.D.; CAEMMERER, S. von. Modelling of photosynthetic response to environmental conditions. In: LANGE, O.L.; NOBEL, P.S.; OSMOND, C.B.; ZIEGLER, H. (Ed.). Physiological plant ecology. Berlin: Springer-Verlag, 1982. p.549587. (Encyclopedia of plant physiology. New series, 12B).

GONÇALVES, J.F. de C.; MARENCO, R.A.; VIEIRA, G. Concentration of photosynthetic pigments and chlorophyll fluorescence of mahogany and tonka bean under two light environments. Revista Brasileira de Fisiologia Vegetal, v.13, p.149-157, 2001.

HENMAN, A.R. Guarana (Paullinia cupana var. sorbilis): ecological and social perspectives on an economic plant of the Central Amazon basin. Journal of Ethnopharmacology, v.6, p.311-338, 1982.

HENMAN, A.R. O guaraná: sua cultura, propriedades, formas de preparação e uso. São Paulo: Global, 1986. 77p. (Cadernos de vida natural, 10).

KRAMER, P.J.; BOYER, J.S. Water relations of plants and soils. San Diego: Academic Press, 1995. 495p.

KRAUSE, G.H.; WEIS, E. Chlorophyll fluorescence and photosynthesis: the basics. Annual Review of Plant Physiology and Plant Molecular Biology, v.42, p.313-349, 1991.

LIETH, J.H.; REYNOLDS, J.F. The nonrectangular hyperbola as a photosynthetic light response model: geometrical interpretation and estimation of the parameter. Photosynthetica, v.21, p.363-366, 1987.

MARENCO, R.A.; GONÇALVES, J.F. de C.; VIEIRA, G. Leaf gas exchange and carbohydrates in tropical trees differing in successional status in two light environments in central Amazonia. Tree Physiology, v.21, p.1311-1318, 2001.

NASCIMENTO FILHO, F.J. do; GARCIA, T.B.; SOUSA, N.R.; ATROCH, A.L. Recursos genéticos de guaraná. In: SOUSA, N.R.; SOUZA, A.G.C. (Ed.). Recursos fitogenéticos na Amazônia Ocidental: conservação, pesquisa e utilização. Manaus: Embrapa Amazônia Ocidental, 2001. p.127-142.

NOBEL, P.S. Physicochemical and environmental plant physiology. San Diego: Academic Press, 1991. 635p.

QUILES, M.J.; LÓPEZ, N.I. Photoinhibition of photosystems I and II induced by exposure to high light intensity during oat plant growth: effects on the chloroplast NADH dehydrogenase complex. Plant Science, v.166, p.815-823, 2004.

REICH, P.B.; WALTERS, M.B.; ELLSWORTH, D.S.; VOSE, J.M.; VOLIN, J.C.; GRESHAM, C.; BOWMAN, W.D. Relationships of leaf dark respiration to leaf nitrogen, specific leaf area and leaf lifespan: a test across biomes and functional groups. Oecologia, v.114, p.471-482, 1998.

RINTAMÄKI, E.; SALO, R.; LEHTONEN, E.; ARO, E.-M. Regulation of D1-protein degradation during photoinhibition of photosystem II in vivo: phosphorylation of the D1 protein in various plant groups. Planta, v.195, p.379-386, 1995.

SHARKEY, T.D. Estimating the rate of photorespiration in leaves. Physiologia Plantarum, v.73, p.147-152, 1988.

Received on September 29, 2004 and accepted on November 4, 2005 